\title{
Female Playwrights and the Theatre in India: Challenges and Perspectives
}

\author{
Indu Pandey \\ University of Delhi, India
}

Playwriting is a mixture of site, history, representation and audiences within the context of ideology. It tries to establish relationship between the reader and the text. "Playwriting, which is an intricate and complex interweave with site, history, representation and audience as well as conventions of realism, narrative and stage practice, emerges as a crucial arena of exploration for contemporary feminism, providing insights into the politics of writing and the possible basis for a feminist theory of reception"(Forte, 1996, p. 19).

The 'fact of power' accounts for much of the lack of appreciation of women's texts; until there is an appreciable change in power structure, it is unlikely that women's fictional accounts of their lives lying in drawing rooms, the parlour, the nursery, the kitchen, the laundry will have the force to induce masculine jouissance (1996, p. 28). Men's traditional disregard for women's writing and women's mode of existence is caused due to the reality of male power.

As Brecht noted, "the theatre as we know it (he calls it illusionism) shows the structure of society (represented on stage) as incapable of being influenced by society (in the auditorium)" (1996, p. 22). The Play maintains illusion of reader as subject who shares with the absent narrator the position of ultimate understanding.

Theatre has been used as a means of communicating protest against any form of violence and oppression. It is a broad term which includes dramatic literature and performance. Theatre has replaced books or films which are considered as popular means of protest. From 1870 onwards, the protest through theatre was directed against social evils in Indian society. The form of theatre differed in pre and post-independence periods. 'Street Theatre" began to be performed at public places in metropolitan cities. It was used to spread awareness regarding women's issues.

Popular theatre was a highly discriminated sphere on the basis of gender. Here, males ruled the female performers who generally came from the courtesans and prostitutes classes. The public sphere was male dominated where only women who were considered as 'public' women were allowed to perform. In male theatrical domain, women were forced to perform roles assigned to them by the male practitioners. Therefore, these women characters got constructed and identified by male playwrights and directors who completely ignored the women centred approach. However, the entry of women practitioners in theatre had led to the questioning of assumed normative discourses. A new kind of theatre started emerging on the horizon which is feminist in nature. This kind of theatre was called 'Stree Preksha' in the ancient India and it is known presently by the name "Feminist Theatre".

The feminist theatre helped in breaking up stereotypical images of women being constructed in theatre by men in the beginning. It has given voice to the silence, reconstructed the traditional images of women and presented them on stage. They try to project sensitive issues concerning 
women in the play so as to spread feminine issues present in the Indian society. Anita Singh in the introduction to her book Gender, Space and Resistance: Women and Theatre writes, "To begin with feminist theatre thrived in cities and towns in India primarily in non-commercial spaces. Jan Natya Manch (People's Theatre Front) of Safdar Hashmi formed in 1973 performed an agitprop street play Aurat (Women, 1979) which dealt candidly with issues like bride burning, dowry and wife bettering" (Singh, 2013, p. 23). Women forayed into the male domain of theatre with the emergence of feminist movement in the Indian theatre. One of the reasons held responsible for the absence of women in theatre is that theatre is a public space and women's exclusion from that space is deliberately done by society. Women is regarded as object/objective/obstacle and necessarily positions in the oppressed subjectivity (which is not subject but object of feminity). They were considered as objects and categorized as the 'other'. The emergence of women's theatre helped women to speak for them and thus become 'speaking subjects'. The public/private divide was broken by these speaking subjects as they became conscious and free to make their own choices and decisions. The Conscious women focused on themselves and stopped depending on the opposite sex.

In the west, women of aristocracy have written short plays but were not recognized until they appeared on stage. The best known and first professional woman playwright was Britain's Aphra Behn. She had become a victim of male prejudice for daring to enter the world of theatre which was a male preserve in those days. Since about 1978 a new feminist-influenced, performancebased work has developed. After the success of feminism, women playwrights came to light and gained equality.

Indian women's theatre came to limelight with women liberation movement of the west. This brought forward gender biased issues into the public arena. Several social issues like dowry deaths, female foeticide, sexual violence, ignorance, illiteracy, gender discrimination in families and society etc. have been exposed by the women's movement in India. Women Liberation Movement moved nations in support of women's fight against oppression. It proved that women are capable of thinking logically and are equally intelligent with respect to their male counterparts. In 1970s, the emergence of urbanization and industrialization created employment opportunities for women. This lead to emergence of sensitive writers who wrote about neglected section of the Indian society. Many tabooed issues found place in the writings of these writers. Women's movement along with socially active Indian theatre began to show way to the oppressed ones. Theatre became medium for creating social changes. Soon, street theatre presented various issues especially those of women from women's perspective.

Some of the Indian pioneers of feminist writing in India have shown a greater understanding of Indian life around them. Tuntun Mukherjee writes in the prolegomenon to her anthology Staging Resistance: Plays by Women in Translation thus: "The denial of education to women, the male exclusivity in the print culture, the tendency to 'vulgarise' and 'devalue' oral culture (generally the female domain), the separation of the private and public space have all served to confine women to certain genres and restrict or erase their presences in others" (2005, p. 4). This book tries to make us understand the possible reasons held responsible for the distancing and alienating women from theatre. Further, she emphasizes that "Theatre seems to reflect, like other cultural activities, an institutional structure in which artistic and administrative control still remains largely in the hands of men"(2005, p. 4).This discriminating ideology of male theatrical domain caused production of work that could be defined only in patriarchal terms. Theatre is regarded as an institution which still is controlled by males. It clearly indicates the role played by both the sexes in the public sphere. Here, women are restricted to the private domain, which is family where the most important task is the reproduction and bringing up the progeny. 
Women writers were trying to break silence and reveal the cause of their sufferings through their work. Their writings are an attempt to reflect the need for change in women's living conditions. Women are compelled to accept their destiny with silence and without any protest. 'Silence' can be seen as something which is forcefully imposed on women in a patriarchal society. Women are never allowed to raise their voice against the evil practices against them and are forced to remain silent throughout their lives. In return, this silence kills them from inside from which they seek escape. Women writers or Women artists felt empowered after entering the field of theatre. Male face dominated theatre for a long time. Women's participation began with the devadasi tradition. Even the female characters were played by male actors. Eventually, women got their voices and started representing themselves. Women playwrights and directors started writing for increasing female performers in theatre. This created a women centric approach in theatre women's experiences and thoughts became the subject of the plays. A series of theatre festivals and workshops were organized by various theatre groups to celebrate the cause of women. To cite a few examples - Akka, the National Women's Theatre Festival held in Mysore, 2001, National Women's Theatre Festival organised by Yavanika, a Hyderabad based Theatre group, Prithvi Theatre from Mumbai, National Workshop on Women, Poorva, Rangkarmee from Kolkata etc.

Owing to its prejudices The Indian People Theatre Association (IPTA) failed to recognize achievement of women artists in a proper perspective and "Most of the Indian theatre women personalities were neglected because all of them belonged to the community of prostitutes, singers and harlots" (R.G.Mahapati, 2008, p. 109). With the changes in times and perspective, it has become inevitable to treat women not as inferior to her male counter parts. So, It's time for women to make their own identity. There is an urgent need to recognize women in a proper perspective and look upon their problems without any kind of discrimination. The best means to achieve this is Theatre which is considered a medium in the service of women's empowerment.

In the context of modern Indian theatre, the location of women playwrights and directors is complex and demands a flexible approach. The Women theatre is predominantly concerned now with social change and feminist ideology. There is a fundamental difference between feminism and theatre; while Feminism comes under cultural politics, Theatre is an act of performance. Susan Basnett says that feminist theatre is based on seven demands: equal pay, equal education and opportunities, financial and legal independence and end to discrimination against lesbians and women's right to define her own sexuality and freedom against violence (Mukherjee, 2005, p. 14). In the west, contemporary feminist theory regards feminist theatre in a political context. So, feminist theatre was written and directed by women. "According to Lizbeth Goodman's argument for flexible feminist theatre, Feminist theatre will be defined in a flexible way as that theatre which aims to achieve positive revaluation of women's roles and / or to effect social change, and which is informed in this project by broadly feminist ideas" (Subramanyam, 2002, p. 21). The play highlights the hopelessness and degradation of women's lives in the patriarchal society, which is an attempt to study a well-known realist text and its relationship to feminist agenda. On the other hand Women's theatre aims at raising consciousness to improve the social conditions for women. It is basically concerned with the projection of women's point of view and is produced by women with feminine concerns directed towards change. Feminist theatre questions the existing realities, social norms and practices that are against women. Its main aim is to enable changes in women's lives through theatrical representations. The debate in feminist criticism regarding playwriting has focused on the question whether a realist play could ever be considered a feminist play. But, Feminist Playwrights should not only write in realistic mode in order to be produced but also face inherent challenges in garnering support for the empowerment of women writers and performers. 
The women writers in English literature can be broadly classified into three categories. The first category consists of writers who are writing before the emergence of feminism as a well-defined forte. In this phase, women writers were struggling hard to be acknowledged on par with men among the intelligentsia. The second category in the order is the feminist writers who wrought the essential rebellious spirit against the male chauvinism and talked of women's emancipation, individuality, and their socio-economic and political equality. This group revolted against patriarchy and demanded freedom from male dominance. The last category tries to strike a balance between the two afore said groups. Here, too one can find an emphasis on the sense of suffocation in a patriarchal society complimented by an acute awareness about rights and equality. However, this group talks less about social and political freedom (Khan, 2006, p. 50).

Both the western and Indian dramas, which are phallocentric in chatrecter, have focused mainly on man and looked at the world through man's eyes. Drama mainly focuses on social issues and holds up mirror to the contemporary society. As such women playwrights, being victims of gender restrictions, remained absent from theatrical world for a very long time. While we find a large number of women making mark in different genres and sub-genres such as poetry, novel, short story, autobiography and fiction, their number is conspicuously low in the field of drama in India. Women playwrights did not write any play till the twentieth century. "As playwrights, women scarcely figure on the literary map. They seem to have shied away from writing plays though they have excelled in all other genres" (Mukherjee, 2005, p. 5).Women writing in other genres like novels, short stories, autobiographies, poetry etc. have performed very well.

Women's writing tries to protests against the male dominance, repression, division, alienation and marginalization and thereby offers a different perspective and opinion. Women performed in the earlier phase very happily to the script written by male playwrights. They had neither their voice nor their words to expresses themselves. They had no option but to read out or speak words written by male writers and perform roles created out of their imagination. Though many male playwrights talked about women's issues, their presentation lacked the authentic ring of women's emotions and feelings. The contrary is true of the women writers. In her interview with Mahesh Dattani published under title "Dialogue with Dattani" in her book Muffled Voices: Women in Modern Indian Theatre, Laxmi Subarmanyam asks Dattani about the reason behind dearth of women playwrights in the modern Indian theatre. Dattani cautiously shares his observation thus: "women playwrights write about strong feminine concerns or simply write about women for no political reasons (same as male playwrights write about men without really thinking about it)". However, "theatre companies prefer to do plays with a male protagonist" and this may be reason for "less female representation among visible playwrights" (2002, p. 20). Many men who run theatre do not take women playwrights seriously because they find it hard to connect to the stories written from a female perspective. This adversely effected women who wanted to pursue their career in the field of Playwriting.

The women playwrights who are remembered for their remarkable contribution are Deena Mehta, Manjula Padmanabhan and Polie Sengupta. They have introduced new subjects affecting the feminine psyche in their works. Deena Mehta is a playwright and an editor from Mumbai. Her first full length play was The Myth Makers (1969). Her play Brides are not For Burning (1993) won the first prize in worldwide competition sponsored by BBC in 1979. Some of her well known plays are Getting Away with Murder, When One Plus One Makes Nine, Sister Like You etc. Next is Manjula Padmanabhan who won the inaugural Onassis Prize for her play Harvest. She has written powerful plays, comic strips, short stories, novel for children, travelogue, picture books, autobiographical novel and Illustrator. Her well known plays are Lights Out, The Artist Model, Sextet and Harvest. Polie 
$51 \mid$ Female Playwrights and the Theatre in India: Challenges and Perspectives

Sengupta was born in Kerala in 1948. She has won the Sandesha Special Recognisation Award for Children's Literature in 1994. Her first play is Mangalam. Apart from this, she wrote Keats was a Tuber, Samara's Song etc. She is also a founder of theatre club. Recently, she published her novel titled Inga.

Women writers in India keep on writing about complex issues such as sensuality, subjugation, alienation, migration, identity crisis, free sex etc. The contemporary women writers were always considered inferior to their male counterparts their canvas was narrow and they largely confined themselves to the depiction of the enclosed domestic space and their experience within it. In spite of the limitations they have definitely raised the consciousness about the woman's role in the society. The portrayal of women characters by a women writer is always realistic and as such authentic. Portrayal of women and their issues by a male playwright tends to be a little unconvincing as he fails to understand the female psyche and perspective. Only a woman playwright like Manjula Padmanabhan could write a play like Lights Out about women's objectification and victimization. This play poignantly depicts an incident like gang rape and captures the reaction of both the males and females of the house over the incident.

Without doubt, plays by women are powerful in their tackling of more complex themes and depicting issues affecting their everyday life in greater depth. Michelene Wandor writes in Feminist Review: "Of Course, the woman playwright does not personally stand up and make a speech in her own voice, putting her own views and convictions, but she engages with something which is unconsciously felt as a far garter threat: she provides a text and meanings which others must follow. In her own voice, refracted through dialogue and structure of the play, she communicates to her audience. She also controls the voice of others. She gives the performers the words which they must speak" (Wandor, 1984, p. 85). In order to remove the gender gap in theatre, it's necessary for female playwrights to keep writing plays because they their voice and power.

Theatre, like most of the other art forms has been a male dominated field. Whenever we think of great playwrights, we have a long list of male playwrights starting from Shakespeare to Bertolt Brecht. Women as dramatist were rarely present in literary history. They were kept away from stage as stage never belonged to them. Absence of women playwrights could be accounted for by the fact that theatre was a public space along with the problem of publication, public performances etc. If woman as a playwright entered the domain of theatre, she was considered a woman first and a writer next. Now that women have entered the theatre as playwrights, they have shaped theatrical techniques which have no author defined consciousness, no resolutions, even tried to build a new class of audiences who would not expect to be entertained. After successfully establishing themselves as accomplished artists, women playwrights have now created plays which are critical the institution of marriage and family hierarchy. They have written plays with strong, complex female characters that demolish the cultural barriers which are discriminatory in character. Theatre can take measures like sponsoring workshops for play readings to develop playwriting skills and encourage female playwrights. 


\section{Works Cited}

Forte, J. (1996). Realism,Narrative, and the Feminist Playwright - A Problem of Reception. In H. Keyssar, New Casebooks: Feminist Theatre and theory (pp. 19-32). Malaysia: Macmillan.

Khan, M. (2006). Distinctive Feminine Concerns in Kamla Das' Poems. In B. Mishra (Ed.), Critical Responses to Feminism (1st ed. ed., pp. 49-59). New Delhi: Swarup \& Sons.

Mukherjee, T. (2005). Staging Resistance: Plays by Women in Translation. New Delhi: Oxford University Press.

R.G.Mahapati. (2008). Women in Theatre. In S.Prasanna (Ed.), Silent Sufferings and Unheard Agony in the Regional Writings on Women (1st ed. ed., pp. 108-111). New Delhi: Sarup\& Sons.

Singh, A. (2013). Gender, Space and Resistance: Women and Theatrein India. (T. T. Anita Singh, Ed.) New Delhi: D.K.Agencies.

Subramanyam, L. (Ed.). (2002). Muffled Voices: women in modern indian theatre. New Delhi: Har-Anand Publicatons Pvt Ltd.

Wandor, M. (1984, Novemember). The Impact of Feminism on the Theatre. Feminist Review (18), 76-92. Retrieved august Sunday, 2015, from http://www.jstor.org/stable/1394862

Indu Pandey is a Research Student at Department of Modern Indian Languages and Literary Studies, University of Delhi, India. 